\title{
Extractive Pluralities: The Intersection of Oil Wealth and Informal Gold Mining in Venezuelan Amazonia
}

\author{
Amy Penfield
}

\section{INTRODUCTION}

The image is becoming increasingly familiar: rows of muscled warriors clad with bright feather headdresses and heavy bead collars march forward. Spears are grasped by some, megaphones by others, with those at the centre clutching banners loudly denouncing mining in bright red letters. These are perhaps the more striking-and certainly most wellknown-images of indigenous responses to mining in South America. There are certainly subtler portrayals depicting steadfast but wise spokespersons fighting for the dignity of their people amidst oil prospecting and large-scale gold mining projects on indigenous territory, among them Davi Kopenawa Yanomami of the lowlands and Máxima Acuña de Chaupe of the Andes. Both these forms of representation portray resource extraction as the epitome of environmental degradation, unethical treatment of local communities, and neoliberal power differentials that generate poverty on a global scale (see e.g. Kirsch 2014; Li 2015;

\footnotetext{
A. Penfield $(\bowtie)$

University of Copenhagen, Copenhagen, Denmark
}

(C) The Author(s) 2019

C. Vindal Ødegaard, J. J. Rivera Andía (eds.), Indigenous Life

Projects and Extractivism, Approaches to Social Inequality and

Difference, https://doi.org/10.1007/978-3-319-93435-8_3 
Sawyer 2004; Shever 2012). If local populations seem not to be outwardly rejecting mining, then at the very least they are expected to promote sustainability as a part of their intrinsically environmentalist ethos.

Resounding tropes of resistance, while pertinent accounts of indigenous reaction to extraction in many settings, may in other cases eclipse more understated and multifaceted responses that digress from, and perhaps even clash with, these popular representations. In other words, 'green-washed' depictions of indigenous resistance to extraction and their inherent conservationist ideology risk oversimplifying indigenous relationships with states, industries, and the environment. This is not to suggest that indigenous peoples welcome extraction with open arms, but that their response is more layered than it might at first appear, and perhaps interwoven with their social and cosmological ethos (see also Ødegaard, this volume). John-Andrew McNeish (2012) points out that outright rejection of resource extraction among indigenous peoples in South America is in fact quite rare. He shows that their narratives on environmental protection are just one in a constellation of interests that emerge in the face of these encroaching activities, with matters of autonomy, community well-being, and compromise often taking a far more prominent place within broader concerns (see also Anthias 2016). How, then, might we evaluate the transformation of indigenous life projects in the contexts of resource extraction when seemingly counterintuitive realisations are unveiled?

My doctoral fieldwork drew attention to disjunctures such as these. During 24 months living with a hunting and horticulturalist indigenous Yanomami subgroup called the Sanema, I noticed that extractivism was central to their burgeoning relationship with the state and to transforming ideas of personhood in unanticipated ways. Their engagement with extraction was not one of antagonism and resistance, but, on the contrary, of gradual-albeit fraught-absorption into the much desired wealth of the petroleum-financed economy and the global gold market. Their unique location in the resource-rich forests of the Venezuelan petro-state has meant that extraction has a twofold bearing on their lives: first as an indirect phenomenon in the form of oil wealth dispensed to Venezuelan citizens and second as the intimate reality of gold mining in their territory. In this sense, extraction is a plural experience in Sanema lived worlds, with multiple and significant impacts on their daily lives. On the one side, the wider economic experiences of engaging more directly as citizens of a petro-state offers opportunities never before experienced. Oil extraction, although a 
process far removed from everyday Sanema life, indirectly influences their contemporary encounters with national society and political engagement. On the other side, intimate encounters with and participation in small-scale gold mining results in more direct but ambivalent evaluations of resources, specifically concerning nonhuman animacy and related notions of morality, as well as the promise of fortune. Thus, both forms of extraction interlace in subtle ways to create a mix of both hope and anxiety among my Sanema interlocutors.

The ethnography outlined in this chapter shows that Sanema life projects are intimately bound up with the pluralities of extractivism, and, furthermore, divergent to the more common tropes of opposition to large-scale mining companies. Crucially, however, this dual engagement plays out as a gradual and complex integration into national and global economies.

\section{Resource as a Political Encounter}

The essential substance that places Venezuela squarely on the resource map-oil-is central to Sanema contemporary life. This is not because the Sanema inhabit lands rich in petroleum as in Ecuadorian Amazonia (see Cepek 2012), but because oil seeps into political possibilities and civil imaginaries in ways that cannot be overestimated, even for ostensibly isolated indigenous communities. This has been the case since the discovery of oil in Venezuela in 1908, ${ }^{1}$ but all the more so since the commencement of the socialist 'Bolivarian Revolution' ('Bolivarianism'), ${ }^{2}$ forged by the late Hugo Chavez. President Chavez proudly declared this a movement of 'twenty-first century socialism,' a regime of social welfare reforms and poverty-reduction measures - from free education and healthcare to subsidised food-implemented to provide for the entire Venezuelan population. Most significantly, this political strategy was financially bolstered by the immense hydrocarbon reserves of the country, and indeed its specific purpose was to redistribute oil wealth to citizens whose access had previously been restricted: poor barrio dwellers, women, and indigenous peoples among them. As such, during the early years of Bolivarianism, greater interest in the nation's indigenous peoples emerged side by side with the significant and interrelated factors of a spike in oil prices, a rise in popular politics, and the flood of petro-dollars into Venezuelan public life.

During my fieldwork between 2009 and 2011 in southern Venezuela, Chavez's polarising renown, paralleled by the inflated price of oil, was at 
its zenith. His policies and charismatic personality were at the centre of widespread and impassioned debates among the general population, and I witnessed them daily from non-indigenous (criollo) acquaintances, taxi drivers, shopkeepers, bureaucrats, and even my Sanema interlocutors. For those opposing his rule, he was nothing more than a populist autocrat who divided the population and swindled the nation's wealth, which alongside strict economic regulations caused what would ultimately be economic collapse. Many, however, supported his programme to empower previously disenfranchised peoples through participatory democracy and equal economic opportunities. Indigenous peoples stood, for the first time, in the spotlight of this era of inclusion. Theoretically at least, spaces for recognition were carved out in political settings: in the national assembly, in a new Ministry of Popular Power for Indigenous Peoples, in promises of legislative reform, and in the newly drafted constitution of 1999. The constitutional amendments, which were implemented directly after the election of Hugo Chavez, included a new section on native peoples, recognising their rights to distinct cultures, languages, schooling, traditional health practices, and territory.

My Sanema hosts benefitted from this new recognition, but not, perhaps, as you might expect. Most Sanema people I spoke to were not aspiring to gain political recognition within this multicultural framework, at least not recognition as indigenous peoples with specific rights. This is in part because, broadly speaking, the Sanema have a weak sense of ethnic identity as they have only very recently had contact with states and the associated political ideologies that prompt notions of bounded ethnic groups (see Brown 1993; Taylor 1997; Whitehead 1999; Wroblewski 2014). To a degree, the Sanema choose to align themselves more closely with their neighbouring Carib-speaking group with whom they share a territory-the Ye'kwana-than they do with other distant Sanema peoples (see Penfield 2017). ${ }^{3}$ In contrast to the Sanema, the Ye'kwana are politically savvy (see Lauer 2006) and have established their own tribal council (KUYUJANI) that protects the rights of indigenous peoples in the region that they inhabit. On paper, this organisation claims also to represent the Sanema by including them in their lobbying activities and regular meetings. Active participation on the part of the Sanema, however, is minimal and, when asked, they seemed rather indifferent; as one stated to me, 'We used to go to meetings with the Ye'kwana, but they never listened to us, so we stopped.' Broader ethnic and interethnic collaborations on the part of the Sanema tend to be premised on dependency, trade, or a desire to 'be like the criollos 
(non-indigenous peoples)' (see Penfield 2016). Political cohesiveness, multicultural activities, or resistance to state activities in their territory was never a topic of conversation during my two years living among them.

Rather than asserting claims for specific cultural rights-a movement they were unacquainted with-something entirely different was going on. During the time of fieldwork, my Sanema hosts were actively engaged in another, perhaps directly contradictory, political agenda. They desired to become subsumed into the Bolivarian Revolution as citizens of a wealthy oil state. That is to say that they were-knowingly or otherwise-drawn into a homogenising 'criollo-isation' of political recognition. I shall utilise Valdivia's term 'petro-citizenship' to describe this engagement, which she characterises as a politico-economic configuration associated with petroleum governance that 'shapes not only people's belonging within the boundaries of the nation, but also political identities through which to claim rights to the benefits associated with national membership' (Valdivia 2008: 457). Hence, the Sanema were gradually developing into petrocitizens (or 'petro-project citizens,' as I describe below) who benefited from the same oil-funded provisions and rights as all Venezuelans. While the newly drafted 1999 constitution testified to upholding rights to traditional cultures, equal and democratic rights were arguably promoted with greater fervour. The provincial office of the Ministry of Popular Power for Indigenous Peoples nearest my field site, for instance, was more often than not promoting elections, standardised development projects, grants to attend high school in the cities, and football tournaments, rather than multicultural initiatives related to indigenous religions, languages, healthcare, or education. This is where we see how petroleum-funded resources become a political encounter. Although the process of extraction is far removed from daily Sanema life, the nation's oil is experienced as the pervasive and financially prosperous socialist projects of Bolivarianism.

\section{Petro-Project Citizenship}

The dispensation of oil wealth also comes in the form of cheap gasoline, the highly subsidised and ubiquitous oil derivative that, as will be discussed in the next section, is used to facilitate other forms of extraction (see Penfield forthcoming). ${ }^{4}$ Indigenous peoples are allocated a monthly quantity of gasoline, typically several large 200-litre drums, that only they are entitled to transport within indigenous territory if accompanied by the mandatory paperwork. Various military checkpoints currently line Amazonian rivers in 
an effort to mitigate fuel smuggling in the region; they flag down each passing boat and check the gasoline licence, which is normally only administered to indigenous residents. The fuel is proffered as a means to feed their growing dependence on gasoline-run machinery, but their rights over large quantities also give them considerable power over this highly valued substance in Amazonia. However, it is the grassroots development projects, the 'petro-projects' if you will, known as 'communal councils' (see Ellner 2009; Valencia 2015; Wilde 2016), that are the medium through which indigenous peoples experience most directly the wealth of the petro-state. These 'communal councils' (consejos comunales) are development initiatives funded by state petro-dollars deposited directly into community bank accounts, later used for projects that are implemented by the communities themselves. Since the passing of the Law of the Communal Councils (Ley de los Consejos Comunales) in $2006,{ }^{5}$ a large proportion of indigenous communities have set up, or are in the process of setting up, communal councils in their forest settlements. By the time of my fieldwork in 2009, many had already reaped the benefits of infrastructural development through their communal councils-water purification systems; tools for farming cooperatives; boats; outboard motors; school buildings; and clinics-while others were beginning the long application process and the esoteric bureaucratic procedures required to set one up (see Penfield 2016).

When I arrived in my Sanema host community to commence fieldwork in 2009, it struck me as unlike any other settlement I had visited prior to that point. After walking up the short path from the river port, what came into view was an unusual hodgepodge of structures. There were the anticipated flimsy pole and thatch household dwellings, but sprinkled between them were a number of odd-looking buildings made from breeze block, metal, corrugated iron, and solar panel-clad roofs. At the far side of the community, peeking above all other structures like a clumsy giant, rose a steel tower with a large metal tank triumphantly perched on top. What was also striking about these awkward-looking buildings was the fact that they were all noticeably incomplete. I later learned the intended purpose of these irregular structures: one was a breeze block school building with already crumbling half-erected walls; another a canteen that had proceeded no further than a large corrugated iron roof; and finally a water purification tower that stood rusting and abandoned, having never delivered one drop of water in its many years since being built. I was soon to discover that all these constructions were the result of projects funded by the settlement's communal council that had been set up in 
the years prior to my arrival. The community explained that the president of the communal council had not done a good job of managing their money. Other communities, in contrast, were perceived to administer their communal councils more effectively; one resident told me these other settlements had 'received the same amount of money but their schools are much better with proper walls and a door and a cement floor.' During that time, members of my host community were in the process of discussing how they could appoint a new president for the communal council and subsequently apply for the release of additional funds, remaining hopeful that the buildings would one day be completed.

It gradually became clear to me that the Sanema's burgeoning relationship with the socialist regime was realised most strikingly through continual struggles to manage their oil-funded communal councils. Infuriated discussions frequently revolved around their failure to navigate bureaucratic procedures, hiring non-indigenous labourers for construction projects they had no skills to undertake themselves, and budgeting so that the enormous funds allocated could be monitored and spent responsibly. In spite of these shortfalls, their newfound acquaintance with the workings of communal councils was infused with hope and ultimately became emblematic of their politicisation as active petro-citizens. Even since Chavez's death, many Sanema continued to be very much immersed in a setting in which citizenship is mobilised by the dispensation of oil wealth. After the election of the new Venezuelan President Nicolás Maduro in April 2013, I called one of my Sanema friends to find out his views on the recent dramatic changes. $\mathrm{He}$ exclaimed without hesitation that 'we, the Sanema, are with Maduro because he gives us lots of credit,' a statement that powerfully underscores the continuity of this political engagement through the distribution of wealth funded by oil. Yet, encounters with extraction do not take place solely at the level of national political and economic ventures. The Sanema also engage with resources on a far more intimate level.

\section{Extraction as an Intimate ReALity}

Engaging in participatory democracy as petro-citizens is only one component of the Sanema's dual encounter with extraction. Since at least 2005, the Sanema have also had an immediate encounter with extraction in the form of gold mining in their territory, activities that have provoked a blend of anticipation, anxiety, and puzzlement. In part due to the informal nature of this activity, Sanema experiences with mining are not consistent with the 
common trope of opposition to powerful 'leviathans' (Golub 2014). Despite being a form of artisanal mining, the large number of indigenous and non-indigenous individual prospectors entering these faraway regions of Amazonia in search of gold creates a form of large-scale open-cast extraction with considerable impact on the environment. An extensive area had reportedly been deforested and a rudimentary camp grows bigger by the day. Referred to locally as minería ilegal, these informal mines are largely obscured due to the remote location of the site, where small crews work with large hydraulic water cannons that blast large craters into the earth. ${ }^{6}$ The resulting sludge that fills these openings is poured over a carpet-lined sluice box, and the heavy sediment that settles is then mixed with mercury to create a gold amalgam. This clandestine but legendary mine was visited with greater frequency by my Sanema hosts because, much like the Bolivarian Revolution, it offered opportunities never before known. The Sanema do not earn money by working in the mine site itself, due, they repeatedly told me, to a general aversion to the mine site and its workers, along with an acute fear of removing gold from the earth, as discussed below. Instead, they make the laborious journey to the hinterland location and offer supplies such as food and gasoline to the labourers and owners of the mining machinery in exchange for gold. I was regularly told that the Sanema could potentially make tremendous riches that would enable them to, as one man stated, 'all return home rich!' Despite these pragmatic motivations, mining activities were also accompanied by a profusion of judgements and concerns relating to gold's cosmological origins.

Although the phenomenon of resource extraction in indigenous territory is often explored in relation to themes of land and land rights, we might question what people mean when they speak of land. It is particularly interesting to note that in scholarly literature the concept of land in Amazonia is often analysed as territorial space or a topographical system, particularly in relation to conceptualisations of powerful others or nonhuman beings who inhabit nearby forest spaces (see e.g. Alexiades 2009; Ewart 2013; Reig 2013). Literature from the Andes, on the other hand, places the earth at the centre of the analysis, the land itself (see Canessa 2012; de la Cadena 2015; Harris 2000). This divergence in ethnographic accounts of what land encapsulates might emerge in part from a focus within Amazonian scholarship on the plethora of beings that inhabit the rich forest landscape-peccaries, monkeys, jaguars, and giant ceiba trees-which in some ways overshadow any insights into the land itself (see Rival 2002). The Andean landscape, on the other hand, which is far sparser in animal and plant life, becomes a habitat where animate beings permeate the earth 
rather than roam and grow above it. In other words, nonhuman life in the lowlands has long been explored as animals and trees and in the highlands as infused within the mountains, the lakes, and the land (see de la Cadena 2010; Sallnow 1989; Sax 2015).

In cases of mining in the Andes, telluric animacy has been associated with a necessary negotiation with supernatural forces, in which miners provide offerings to the spiritual guardians of the earth (Supay) in order to bring good fortune and mitigate danger (Nash 1993). In addition to requiring recompense for resources extracted, these occult forces might attack out of sheer malevolence (see Sallnow 1989). While frequently portrayed as hostile, Andean land also has a tenacious quality as a resolute environmental activist. Marisol de la Cadena (2010), for instance, suggests that we consider the mountain Ausangate in Peru as a powerful political activist in its own right, a wilful intentional agent who opposes mining concessions in its foothills so severely that it threatens to kill those occupying its lands. She does not present the mountain as benevolent per se, but rather as a political liberator and guardian of indigenous worldviews. Even in this case, the land is valorised as a prudent protector of the pristine, the virtuous, and the sustainable.

While indigenous Amazonians are equally thought to be guardians of the environment who fight to safeguard their territory, depictions of the actual earth within this broader discourse of environmentalism, and notions of what might be extracted from the earth, are few and far between. One notable exception is Michael Cepek (2016; see also Krøijer, this volume) who has described how Cofán conceptualise the extraction of oil on their territory as intimately bound up with its placement beneath the earth, because subterranean entities 'have a form of animacy that is normally the unique property of humans' (Cepek 2016: 27-28). Indeed, it is precisely this underground location that thrusts oil into the realm of unpredictability. Nevertheless, this is not an exclusively indigenous perspective, as non-indigenous garimpeiros also regard gold's telluric origins as the primary source of its force, taking form in miners stories as an alluring woman or blood-seeking animal, both representations that parallel a supposed 'absence of clear-cut morals' (Slater 1994).

Jacques Lizot has noted that the Yanomami consider the ground a place of multiple layers, infused with 'rottenness, inhabited by grotesque, giant worms' (Lizot 2007: 271-76; quoted in Kelly 2011: 235, n. 4). Like the Yanomami, my Sanema hosts see the underworld as a dreadful and ominous place, where expelled illness is thrown during shamanic incantations, 
an action that was strikingly portrayed during my host father's healing sessions in which he gestured a scooping and throwing movement from sick patients while chanting, 'lute, lute, masitali, masitali!' ('it smells bad, it smells bad, in the earth, in the earth!'). Many of my interlocutors described the terrestrial domain as the home of malicious dwarf cannibalbeings known as 'the hungry ones' (obinamo töpö) who emerge from their vile subterranean worlds and voraciously consume the Sanema if puberty rites are not strictly adhered to. Even a baby landing directly on the earth when born is a bad omen, an event that is said to cause lifelong sickness (see also Gow 1989 for other fearful conceptualisations of the earth).

In a footnote to The Falling Sky, Bruce Albert notes that, among the Yanomami, Christian burials in the earth are considered a 'revolting practice' that prevents the parting of the ghost and in turn the cessation of mourning (Kopenawa and Albert 2013: 525, n. 44). Conklin makes a similar observation among the Wari,' who regard burial as horrific because the ground is 'cold, wet and polluting' (Conklin 2001: xviii). One of my Sanema hosts indeed once told me that one must never bury the people they love, but instead 'must do what the ancestors did and burn them.' Apart from this fear of being forever entombed in the cold earth, another woman also stated that vengeful spirits of the dead (nopolipö töpö) live underground, and that the hideous 'man of light' (molökolia) pulls them from the earth and takes them up to the sky on his shoulders. Narrated in the genre of a myth, this terrifying story was reportedly used to prevent young boys from playing in the bright moonlight at night. The gesture of pulling souls from the abominable earth was, one research participant told me with visible unease, an action most appalling to envisage. The subsoil and the occult forces that it harbours in both the Andes (see Stensrud, this volume) and in Amazonia, then, are a source of much anxiety.

It is not surprising, then, that the Sanema's engagement with mining is ambivalent, both because the activity itself invades this menacing telluric realm, but also because the gold residing therein is greedily removed. Gold was described as silimo, or speedy (Spanish apurado); promoting a rapid movement because of its small weightless form, but also due to people's eagerness to bring it back to the commercial centres in order to obtain their long awaited riches. Many rumours circulated about 'the curse of gold,' a relatively widespread phenomenon where informal mineral extraction is concerned (see Biersack 1999; High 2013; Shipton 1989), related to the speedy squandering of gold money so that prospectors are forced to immediately return to the mine to yet again toil away for their treasures. But the 
speediness of gold for the Sanema has an altogether more menacing undertone, and in fact the quick squandering of their wealth was the least of their worries. Over and over again gold was described as having a malevolent force that stems from its derivation beneath the earth. Yanomami activist Davi Kopenawa describes gold as emerging from fragments of stars that were placed under the earth by the mythical hero Omama because such minerals are 'evil and dangerous things, saturated with coughs and fevers' (Kopenawa and Albert 2013: 282). The present-day earth is described as a layer of the sky that fell in primordial time, marking the inception of the modern era. The event itself was catastrophic, followed by the stabilisation of all beings in the cosmos, but also by the onset of all known illness and suffering that evidently originates in part from these beguiling but deleterious resources.

My Sanema research participants described the threat of gold as emerging from its pernicious 'spirit carers,' the orotil töpö (literally, gold people), tutelary spirits who 'look after' gold and enact revenge upon those who remove it from their land, or those who have it in their possession for any length of time. In fact, more often than not, vengeance is obtained by attacking family members of miners or those in close proximity to the gold rather than solely the miners or smugglers themselves, a form of deflected causality common in Amazonia (see Penfield forthcoming). When a whooping cough epidemic acutely afflicted most of the children in my host community, the women blamed the men who had stayed there too long with gold in their pockets on their way down from the mine. They said the children were ill because the gold was enacting retribution. One man described it to me in a hushed voice: 'When you have gold you must leave the community as quickly as possible. It is only when you take it to a trader in the city that you are truly safe.' Another described a time when his father almost died when he had malicious gold in his possession for too long: 'I won't go to the mine because of my father's mining experience in the past. He worked for some Ye'kwana men and they gave him a little bit of gold in payment and he almost died because he brought it to the house and left it there.' Importantly, however, although gold was clearly a dangerous substance with malicious intentionality, this did not stop many Sanema from continuing to pursue mining activities.

\section{The Dangers of Acquiring 'Good Things'}

One might argue that these occult depictions of gold subtly reflect emerging anxieties over extraction in Sanema territory and the changing dynamics that result from these activities: that is, close and regular contact with 
the criollo realm, and the alienation, greed, and breakdown of social ties that are generally thought to result. Indeed, many anthropological studies of mines and mining have shown that the boundary between surface and underground often has profound significance, marking a borderline between life and death, good and evil, human and divine, indigenous and non-indigenous, and so on (see also High 2013: 681 for a case of breakdown of purity and pollution through mining the earth). Taussig's work (1980) - which interprets Nash's account of Bolivian tin miners who make a pact with the devil (Supay, also known as El Tío)—asserts that such actions are a means to mitigate the morally contaminating effects of the capitalist economy and resource wealth (see also Onneweer 2014). Yet, to portray similar anxieties as the sole concern surrounding gold extraction in the Sanema case would oversimplify their experiences and overlook a profound conceptualisation of their cosmos and the many relational beings who inhabit it (see also Ødegaard 2017). Moreover, many saw resources as an essential component of community well-being because the riches obtained from mining are compassionately shared with kin.

Among my Sanema hosts, contentment (pi mönaja) was often expressed as realised through the receipt, sharing, and bestowal of material things within kin circles, predominantly manufactured goods (matitö), which were explicitly referred to as 'good things' or 'things we want.' The term for 'suffer'-pebalo - also means 'to be without things' or 'to be poor,' implying an emotional sadness closely linked to a deficiency in material possessions. ${ }^{7}$ Whereas in the past such suffering may have predominantly been associated with lack of sustenance, such as the meat that kin provide, now it is becoming progressively bound up with goods. Lizot has noted a similar sentiment among the Yanomami: 'If the Indians strive for profit, it is then not for the pleasure of accumulating wealth, but for the prestige and the private satisfaction involved in the division and redistribution of possessions' (Lizot 1991: 184). Sanema men who make an effort to spend periods of time trading supplies at the mine for gold in order to buy their kin clothes, shoes, pots, machetes, and beads are thought to be admirable, caring people. Conversely, those who do not bestow such gifts (tota jötöpo) are presented as inattentive people, likened to enemy others, sorcerers or immoral criollos. Parents of naked children were regularly described as bad parents, expressed by the disparaging phrase 'he leaves his children naked.' Nevertheless, giving gifts to family members is more than merely a generous act, it also protects them from danger. Failure to obtain 'good things' from kin results in anguish comparable to illness, manifesting in a worrying 
withdrawal into one's hammock, a complete abandonment of the community, or even the loss of one's soul. A child who is 'soft' (Sanema osiati) after birth remains so in their naked unadorned form, and can become 'hot,' 'distressed,' or 'sad' without bodily embellishments given by their kin. Hence, the moral primacy of sharing (köpalo) impels one to privilege generosity (öd $\ddot{o} i \ddot{o})$ over the satisfaction of personal desires (see also Storrie 2006: 230).

Compassion through the bestowal of gifts is also notable in the Sanema term used for Bolivarian projects-pasila palai-which describes the material assistance they receive, but also refers to the alleviation of suffering just mentioned. When asked about President Chavez, many of my interlocutors described him in a joyous tone as their father (Sanema ipa jawani) because he cared for them through the bestowal of goods, as would any compassionate kin (see also Caballero-Arias 2003: 358). It is clear to see how participation in the processes of both Bolivarianism and gold extraction-and the goods that issue forth from both forms of engagementfacilitate kin contentment. Even though there is some indication that gold inhabits a dangerous realm, and perhaps even evokes veiled anxieties about the encroaching market economy, Sanema people nevertheless take part in this treacherous activity due to their responsibility as devoted and compassionate kin. In a sense, participation in mining is a trade-off between the dangerous propensity of the vengeful gold and the broader well-being that resources provide (see also Kelly 2011: 65-66).

\section{Conclusion: Extractive Pluralities}

Contrary to the neo-colonial indigenous icons of what have been referred to as the 'ecologically noble savage' (Redford 1991) or the 'hyper-real Indian' (Ramos 1994), the Sanema case underlines the need to look beneath conventional accounts of resistance to resource extraction on indigenous territory. Firstly, the ethnography presented in this chapter has shown not only that oil-funded projects have initiated new forms of political engagement and citizenship but also that they facilitate sociality at the local level through the management of petro-projects. Secondly, for the Sanema, nature is not conceptualised as a pristine ecosystem that requires protection; at best it is an environment that exists to be exploited and at worst it is the realm of the wicked. Rather than valorising nature and acting as its guardians, then, the Sanema view it-in particular the subsoil-as a terrifying vengeful domain, a prototypical 'other' that is not protected but warily 
manipulated. Participation in small-scale gold mining results in more direct but ambiguous encounters with resources; experiences which, although manifesting as troubled assessments of gold's animacy, do not entirely curtail the desire to participate nor stymie the promise of ensuing fortune.

Both forms of extraction facilitate the realisation of compassion among kin through the wealth acquired. As such, rather than adhering to accounts of occult economies in representing a denunciation of the morally contaminating capitalist economy, other facets of daily life must be taken into consideration. In order to be a convivial and self-sufficient unit, for example, the Sanema must engage with the wider national economyeven though experienced as a 'trade-off'-in order to access the goods that make their kin content, a materialised expression of compassion and generosity (see also Walker 2013). Contrary to the perception that incorporation into the extractive economy brings with it individualism and social degeneration, in the Sanema case it is a sign of the hard work one has undergone to obtain goods for kin (see also Allard 2010: 26; Alès 2000: 135). Wealth, in this case, is human relationships, not individual self-interest.

What is particularly interesting about this case is the fact that the two realms of extraction are exploited in similar ways, but furthermore, that they are simultaneously intertwined because the Venezuelan petro-state inadvertently buttresses gold mining in the lowland states. As mentioned earlier, the fostering of indigenous political participation not only allows, but in fact requires, them to access large quantities of fuel in order to travel to the cities and navigate political structures with ease. The distribution of oil wealth and the associated allocation of subsidised gasoline results in large quantities of the fuel entering the mine site and feeding the hydraulic cannons that power the mine. In other words, without oil, there would be no gold. One could also argue that not only are these two economies (oil and gold) linked, but that between them stand the Sanema, who are taking advantage of oil wealth distribution to reap the benefits of gold revenue. This shows us, then, that the Sanema's encounter with extraction in its many forms plays out as a gradual absorption into the national and global economies in very subtle ways. It is clear that asymmetries are emerging as a result of this process, particularly notable in the frustrations over communal council management, as mentioned briefly above. However, for the time being anyway, grievances over the emergence of inequalities are not excessively foregrounded. Instead, the Sanema's sense of excited anticipation over ceaseless oil and gold abundance remains at the heart of their daily discussions. Existing betwixt two forms of extraction, 
then, is a complex and multifaceted experience, because engagement with resources precludes any simple dualisms of natural and produced, them and us, well-being and deprivation, sustainable and destructive. It is this complex setting that shapes indigenous life projects in unexpected ways, yet ways that are nevertheless determined by distinct realisations of autonomy and well-being.

\section{Notes}

1. Venezuela has the largest oil reserves in the world, estimated in 2016 to be over 300 billion barrels in total (http://www.opec.org/opec_web/en/ data_graphs/330.htm).

2. This socialist movement was named after the nineteenth century liberator Simón Bolívar, who led the struggle for independence throughout South America.

3. The association between the Sanema and the Ye'kwana consists of a long history of antagonism, predominantly stemming from the Ye'kwana's monopoly over access to manufactured items. Beginning with an extended period of violent raids in the 1930s, the relationship later developed into one of co-dependence in which the Sanema built nearby settlements in order to provide labour in exchange for goods.

4. Gasoline is extremely cheap in Venezuela as a result of a subsidy introduced in the 1940s when the country was gaining prominence as a global producer of oil.

5. Officialised originally on 10 April 2006, code number 5806. The law was updated on 28 December 2009 to the Ley Orgánica de los Consejos Comunales with the new official code number 39335 . Although this was the first law of its kind on community development projects, it was built on already existing practices of neighbourhood organising (junta de vecinos).

6. The term mineria artesanal, on the other hand, refers to the delegitimised practice of gold panning. In the media, the larger open-cast placer mines run by individual prospectors have also been referred to as 'wildcat mines.'

7. Compare to the Quechua term waqcha, which refers to poverty in terms of not having relatives or social networks (see Altamirano 1988).

\section{REFERENCES}

Alès, Catherine. 2000. Anger as a Marker of Love: The Ethic of Conviviality Among the Yanomami. In The Anthropology of Love and Anger: The Aesthetics of Conviviality in Native Amazonia, ed. Joanna Overing and Alan Passes. London: Routledge. 
Alexiades, Miguel N., ed. 2009. Mobility and Migration in Indigenous Amazonia: Contemporary Ethnoecological Perspectives. New York: Berghahn Books.

Allard, Olivier. 2010. Morality and Emotion in the Dynamics of an Amerindian Society (Warao, Orinoco Delta, Venezuela). PhD dissertation, University of Cambridge.

Altamirano, Teófilo. 1988. Cultura Andina y Pobreza Urbana: Aymaras en Lima Metropolitana [Andean Culture and Urban Poverty]. Lima: Fondo Ed. PUCP.

Anthias, Penelope. 2016. Indigenous Peoples and the New Extraction: From Territorial Rights to Hydrocarbon Citizenship in the Bolivian Chaco. Latin American Perspectives 11 (08): 1-18.

Biersack, Aletta. 1999. The Mount Kare Python and His Gold: Totemism and Ecology in the Papua New Guinea Highlands. American Anthropologist 101 (1): 68-87.

Brown, Michael F. 1993. Facing the State, Facing the World: Amazonia's Native Leaders and the New Politics of Identity. L'Homme 126-128: 307-326.

Caballero-Arias, Hortensia Raiza. 2003. Engaging in Politics: Yanomami Strategies in the Face of Venezuela's National Frontier Expansion. PhD, University of Arizona.

Canessa, Andrew. 2012. Intimate Indigeneities. Durham: Duke University Press.

Cepek, Michael. 2012. The Loss of Oil: Constituting Disaster in Amazonian Ecuador. Journal of Latin American and Caribbean Anthropology 17 (3): $393-412$.

- 2016. There Might Be Blood: Oil, Humility, and the Cosmopolitics of a Cofán Petro-Being. American Ethnologist 43 (4): 623-635.

Conklin, Beth A. 2001. Consuming Grief: Compassionate Cannibalism in an Amazonian Society. Austin: University of Texas Press.

de la Cadena, Marisol. 2010. Indigenous Cosmopolitics in the Andes: Conceptual Reflections Beyond "Politics". Cultural Anthropology 25 (2): 334-370.

- 2015. Earth Beings: Ecologies of Practice across Andean Worlds. Durham: Duke University Press.

Ellner, Steve. 2009. A New Model with Rough Edges: Venezuela's Community Councils. NACLA Report on the Americas 42 (3): 11-14.

Ewart, Elizabeth. 2013. Space and Society in Central Brazil: A Panará Ethnography. New York: Bloomsbury Academic.

Golub, Alex. 2014. Leviathans at the Goldmine: Creating Indigenous and Corporate Actors in Papua New Guinea. Durham/London: Duke University Press.

Gow, Peter. 1989. The Perverse Child: Desire in a Native Amazonian Subsistence Economy. Man 24 (4): 567-582.

Harris, Olivia. 2000. To Make the Earth Bear Fruit: Essays on Fertility, Work and Gender in Highland Bolivia, ILAS Series. London: Institute of Latin American Studies. 
High, Mette. 2013. Polluted Money, Polluted Wealth: Emerging Regimes of Value in the Mongolian Gold Rush. American Ethnologist 40 (4): 676-688.

Kelly, José Antonio. 2011. State Healthcare and Yanomami Transformations: A Symmetrical Ethnography. Tucson: University of Arizona Press.

Kirsch, Stuart. 2014. Mining Capitalism: The Relationship Between Corporations and Their Critics. Berkeley: University of California Press.

Kopenawa, Davi, and Bruce Albert. 2013. The Falling Sky: Words of a Yanomami Shaman. Cambridge, MA: Harvard University Press.

Lauer, Matthew. 2006. State-led Democratic Politics and Emerging Forms of Indigenous Leadership among the Ye'kwana of the Upper Orinoco. Journal of Latin American Anthropology 11 (1): 51-86.

Li, Fabiana. 2015. Unearthing Conflict: Corporate Mining, Activism, and Expertise in Peru. Durham/London: Duke University Press.

Lizot, Jacques. 1991. Tales of the Yanomami: Daily Life in the Venezuelan Forest. Cambridge: Cambridge University Press.

- 2007. Yanomami. In Salud Indigena en Venezuela, Volumen I, ed. G. Freire and A. Tillett. Caracas: Ministerio de Salud.

McNeish, John-Andrew. 2012. More Than Beads and Feathers: Resource Extraction and the Indigenous Challenge in Latin America. In New Political Spaces in Latin American Natural Resource Governance, ed. Håvard Haarstad. New York: Palgrave Macmillan.

Nash, June. 1993. (1st ed. 1979). We Eat the Mines and the Mines Eat Us: Dependency and Exploitation in Bolivian tin Mines. New York: Columbia University Press.

Ødegaard, Cecilie Vindal. 2017. Alterity, Predation, and Questions of Representation: The Problem of the Kharisiri in the Andes. In Critical Anthropological Engagements in Human Alterity and Difference, ed. Bjørn Enge Bertelsen and Synnøve Bendixsen. London: Palgrave Macmillan.

Onneweer, Maarten. 2014. Rumors of Red Mercury: Histories of Materiality and Sociality in the Resources of Kitui, Kenya. Anthropological Quarterly 87 (1): 93-118.

Penfield, Amy. 2016. Maneuvering for Paper: Physical and Social Experiences of Bureaucracy in Venezuelan Amazonia. The Journal of Latin American and Caribbean Anthropology 21 (3): 457-477.

- 2017. Dodged Debts and the Submissive Predator: Perspectives on Amazonian Relations of Dependence. Journal of the Royal Anthropological Institute 23 (2): 320-337.

forthcoming. The Fuel of Fright and Force: Gasoline's Energetic Power and Its Entanglement within Human Composite Ethics. Journal of the Royal Anthropological Institute.

Ramos, Alcida R. 1994. The Hyperreal Indian. Critique of Anthropology 14 (2): $153-171$. 
Redford, Kent H. 1991. The Ecologically Noble Savage. Cultural Survival Quarterly 15 (1): 46-48.

Reig, Alejandro. 2013. "When the Forest World Is Not Wide Enough We Open Up Many Clearings": The Making of Landscape, Place and People among the Shitari Yanomami of the Upper Ocamo basin, Venezuela. PhD dissertation, University of Oxford.

Rival, Laura M. 2002. Trekking through History: The Huaorani of Amazonian Ecuador. New York: Columbia University Press.

Sallnow, Michael J. 1989. Precious Metals in the Andean Moral Economy. In Money and the Morality of Exchange, ed. Maurice Bloch and Jonathan Parry. Cambridge: Cambridge University Press.

Sawyer, Suzana. 2004. Crude Chronicles: Indigenous Politics, Multinational Oil, and Neoliberalism in Ecuador. Durham/London: Duke University Press.

Sax, Marieka. 2015. On Place, Well-Being and Illness in the Andes. Indiana 32: 47-64.

Shever, Elana. 2012. Resources for Reform: Oil and Neoliberalism in Argentina. Stanford: Stanford University Press.

Shipton, Parker M. 1989. Bitter Money: Cultural Economy and Some African Meanings of Forbidden Commodities. Washington, DC: American Anthropological Association Monograph Series.

Slater, Candace. 1994. “All That Glitters.”: Contemporary Amazon Gold Miners' Tales. Comparative Studies in Society and History 36 (4): 720-730.

Storrie, Robert. 2006. The Politics of Shamanism and the Limits of Fear. Tipiti 4 (2): 223-246.

Taussig, Michael T. 1980. The Devil and Commodity Fetishism in South America. Chapel Hill: University of North Carolina Press.

Taylor, Charles. 1997. The Politics of Recognition. In New Contexts of Canadian Criticism, ed. Ajay Heble, Donna Palmateer Pennee, and J.R. Struthers. Ontario: Broadview Press.

Valdivia, Gabriela. 2008. Governing Relations between People and Things: Citizenship, Territory, and the Political Economy of Petroleum in Ecuador. Political Geography 27 (4): 456-477.

Valencia, Cristobal. 2015. We Are The State! Barrio Activism in Venezuela's Bolivarian Revolution. Tucson: University of Arizona Press.

Walker, Harry. 2013. Wild Things: Manufacturing Desire in the Urarina Moral Economy. The Journal of Latin American and Caribbean Anthropology 18 (1): 51-66.

Whitehead, Neil L. 1999. Tribes Make States and States Make Tribes: Warfare and the Creation of Colonial Tribes and States in Northeastern South America. In War in the Tribal Zone: Expanding States and Indigenous Warfare, ed. R. Brian Ferguson and Neil L. Whitehead. Santa Fe: SAR Press. 
Wilde, Matt. 2016. Contested Spaces: The Communal Councils and Participatory Democracy in Chávez's Venezuela. Latin American Perspectives 44 (1): 140-158.

Wroblewski, Michael. 2014. Public Indigeneity, Language Revitalization, and Intercultural Planning in a Native Amazonian Beauty Pageant. American Anthropologist 116 (1): 65-80.

Open Access This chapter is licensed under the terms of the Creative Commons Attribution 4.0 International License (http://creativecommons.org/licenses/ by $/ 4.0 /)$, which permits use, sharing, adaptation, distribution and reproduction in any medium or format, as long as you give appropriate credit to the original author(s) and the source, provide a link to the Creative Commons license and indicate if changes were made.

The images or other third party material in this chapter are included in the chapter's Creative Commons license, unless indicated otherwise in a credit line to the material. If material is not included in the chapter's Creative Commons license and your intended use is not permitted by statutory regulation or exceeds the permitted use, you will need to obtain permission directly from the copyright holder.

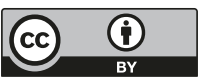

